Original Research Article

\title{
Evaluation of awareness about pharmacoeconomics in postgraduate students of a tertiary care teaching hospital: a questionnaire based observational study
}

\author{
Rohini Gupta $^{1 *}$, Pavan Malhotra ${ }^{2}$
}

\begin{abstract}
${ }^{1}$ Department of Pharmacology and Therapeutics, Government Medical College, Jammu, J\&K, India

${ }^{2}$ Department of Pharmacology and Therapeutics, Acharaya Shri Chander College of Medical Sciences and Hospital, Sidhra, Jammu, J\&K, India
\end{abstract}

Received: 30 July 2017

Revised: 19 August 2017

Accepted: 23 August 2017

*Correspondence to:

Dr. Rohini Gupta,

Email: rohinigupta299@

ymail.com

Copyright: (C) the author(s), publisher and licensee Medip Academy. This is an openaccess article distributed under the terms of the Creative Commons Attribution NonCommercial License, which permits unrestricted noncommercial use, distribution, and reproduction in any medium, provided the original work is properly cited.

\begin{abstract}
Background: Pharmacoeconomics identifies, measures and compares the costs and consequences of drug therapy to health care systems and society. The per capita income of all middle class people is limited and the drug prices are growing extensively. Therefore, it is the responsibility of the health-care professionals to balance both cost and quality of treatment. Hence, this study was planned among the postgraduate students who form the major part of health care delivery system to assess their awareness about pharmacoeconomis.

Methods: This was a questionnaire based cross-sectional study. Selfadministered questionnaire was distributed among 72 residents, out of which 61 completely filled questionnaires were finally used for statistical analysis. The questionnaire contained questions relating to awareness, knowledge, method of application and students' attitude about pharmacoeconomics.

Results: The willingness to participate in the study among postgraduates was extremely poor. Those who have participated, almost $39 \%$ of participants were having awareness about the topic. Nearly $31 \%$ of the participants were having knowledge regarding pharmacoeconomics and around $21 \%$ of participants have learnt the method of application in various aspects.

Conclusions: Study has revealed that that the knowledge and perception level of postgraduates in day to day use of pharmacoeconomic concepts are poor and limited. Therefore, it is very necessary to make them aware about the concept of pharmacoeconomics by incorporationg it in their medical curriculum and by conducting CMEs and Workshops on pharmacoeconomics.
\end{abstract}

Keywords: Awareness, Knowledge, Pharmacoeconomics, Postgraduate students

\section{INTRODUCTION}

Pharmacoeconomics which is a sub-discipline of healtheconomics has been defined as "the description and analysis of the costs of drug therapy to healthcare systems and society". It identifies measures and compare costs (resources consumed) and consequences (clinical, economic, humanistic) of pharmaceutical products and services. ${ }^{1}$
In order to survive and thrive in this recessionary world, pharma and healthcare businesses will have to rigorously perform pharmacoeconomic evaluations. Citizens and Physicians worldwide are increasingly facing problems in deciding which treatment is most effective medically and economically. Pharmacoeconomics evaluates the behaviour of individuals, firms and markets relevant to the use of pharmaceutical products, services and programmes. ${ }^{2-6}$ Economics is all about limited "resources" and unlimited "wants". 
The pharmaceutical industry traditionally viewed communications to the clinicians as one of its most powerful marketing tools and tended to concentrate on the safety and efficacy of medicines. However, the paradigm is now changing, as some pharmaceutical manufacturers are including economic ("pharmacoeconomic") data in their communications. ${ }^{7}$

The objective of pharmacoeconomics is to define the needs of the patient so that available resources can be distributed as per needs of the patient. While prescribing a drug, a large number of drugs are available on brand names but are very costly, while at the same time good quality drugs by generic names are available at half the costs, thus one should preferably prescribe a drug by generic name, of course not compromising on quality. The health care resources are very limited, and the healthcare purchasers are now engaged in finding the ways to contain drug costs without compromising on the quality of medical care. However this can only be achieved if we can get reliable data on costs and benefits. ${ }^{8}$

\section{METHODS}

A cross-sectional questionnaire-based observational study was conducted in Acharaya Shri Chander College of Medical Sciences and Hospital, Sidhra, Jammu, J\&K. The study was done after approval from the Institutional Ethical Commitee. Postgraduate medical students of various departments of our college were included in the study to assess the extent of knowledge and awareness of pharmacoeconomics and its methods of application among the students. The postgraduate students who were not willing to participate in the study were excluded. Selfadministered pre-validated questionnaire was used to collect the data from respondents. ${ }^{9,10}$ The purpose of the study was explained and written informed consent was obtained from all the participants before being given the questionnaires.

The questionnaire consists of two parts. The first part pertained to a collection of demographic information of the postgraduates (age, gender, deptt. and year of experience as postgraduate). The second part of the questionnaire contained multiple choice formats with focus from awareness, knowledge, methods of application and attitude related to pharmacoeconomics. The respondents were asked to select one option which is most appropriate to relevant question according to them.

A questionnaire is said to be standardized when each respondent is to be exposed to the same questions and the same system of coding responses. The aim here is to try to ensure that differences in response to questions can be interpreted as reflecting differences among respondents, rather than differences in the processes that produced the answers. ${ }^{11-13}$ In this study, we followed standard pattern to measure the level of awareness, knowledge and methods of application of postgraduate students on the general topic of pharmacoeconomics. All the survey questions related to basic definitions on concepts of pharmacoeconomics were assigned equal value, i.e. 1 for correct response and 0 otherwise. The responses were reviewed and analysis was done for calculating the overall rating scale by dividing the total number of correct response by the total number of questions and multiplying by 100 . The results were expressed as percentage response in each of three categories from the total as $100 \%$. The final analysis was performed using Statistical Package for the Social Sciences (SPSS, version 17).

\section{RESULTS}

Out of 72 residents, 29 members from Final year students, 17 members from second year students and 15 members from first year students participated in the study. 11 members rejected to take the questionnaire.

Table 1: Percentage response of participants to awareness-based questions.

\begin{tabular}{|c|c|c|}
\hline \multirow{2}{*}{ Questions } & \multicolumn{2}{|c|}{$\begin{array}{l}\text { Response }(\%) \\
\mathbf{n}=61(\mathbf{1 0 0 \%})\end{array}$} \\
\hline & $\begin{array}{l}\text { Right } \\
\text { answer }\end{array}$ & $\begin{array}{l}\text { Wrong } \\
\text { answer }\end{array}$ \\
\hline \multicolumn{3}{|l|}{ Awareness } \\
\hline $\begin{array}{l}\text { Are you aware of the term } \\
\text { "Pharmacoeconomics"? }\end{array}$ & 39 & 61 \\
\hline $\begin{array}{l}\text { Is every teaching hospital in } \\
\text { India are following } \\
\text { pharmacoeconomic guidelines? }\end{array}$ & 62 & 38 \\
\hline $\begin{array}{l}\text { Is Health economics and } \\
\text { pharmacoeconomics are same? }\end{array}$ & 43 & 57 \\
\hline What is Pharmacoeconomics? & 32 & 68 \\
\hline $\begin{array}{l}\text { ECH outcomes in } \\
\text { pharmacoeconomics evaluate }\end{array}$ & 4 & 96 \\
\hline
\end{tabular}

Table 2: Percentage response of students to knowledge-based questions.

\begin{tabular}{|lll|}
\hline \multicolumn{3}{|l|}{$\begin{array}{l}\text { Response (\%), } \\
\text { n=61 (100\%) }\end{array}$} \\
\hline & $\begin{array}{l}\text { Right } \\
\text { answer }\end{array}$ & $\begin{array}{l}\text { Wrong } \\
\text { answer }\end{array}$ \\
\hline $\begin{array}{l}\text { All are different types of } \\
\text { pharmacoeconomic analysis } \\
\text { except }\end{array}$ & 29 & 71 \\
\hline $\begin{array}{l}\text { Following are different types of } \\
\text { cost involved in } \\
\text { pharmacoeconomic analysis } \\
\text { except }\end{array}$ & 33 & 67 \\
\hline $\begin{array}{l}\text { Pain and suffering of patients are } \\
\text { included in----cost }\end{array}$ & 31 & 69 \\
\hline $\begin{array}{l}\text { Robustness of results are best } \\
\text { tested by-----analysis }\end{array}$ & 16 & 84 \\
\hline $\begin{array}{l}\text { Pharmacoeconomic governing } \\
\text { body in India is }\end{array}$ & 9 & 91 \\
\hline
\end{tabular}


All the participants were given the necessary instructions and sufficient time to fill the questionnaire. It was observed that $39 \%$ of the respondents were aware about the concept of pharmacoeconomics (Table 1).

However, the majority of the respondents had little knowledge about the principles of pharmacoeconomics and only $31 \%$ of them responded positively (Table 2). Considering the methods of application of Pharmacoeconomics nearly $20 \%$ of postgraduates were having knowledge about pharmacoeconimcs (Table 3). As far as attitude of students about pharmacoeconomics is concerned total $52 \%$ of postgraduates felt pharmacoeconomics should be included in Postgraduate curriculum. $81 \%$ of postgraduates wanted to conduct continuous medical education on pharmacoeconomics. Only $17 \%$ showed self-interest in learning pharmacoeconomics. $23 \%$ of postgraduates agreed that there is a need of a specialization degree of pharmacoeconomics.

\section{Table 3: Percentage response of students relating to methods of application of pharmacoeconomics.}

\begin{tabular}{|c|c|c|}
\hline \multirow{2}{*}{ Questions } & \multicolumn{2}{|c|}{$\begin{array}{l}\text { Response (\%), } \\
n=61(100 \%)\end{array}$} \\
\hline & $\begin{array}{l}\text { Right } \\
\text { answer }\end{array}$ & $\begin{array}{l}\text { Wrong } \\
\text { answer }\end{array}$ \\
\hline $\begin{array}{l}\text { Most commonly used } \\
\text { Pharmacoeconomic analysis is }\end{array}$ & 21 & 79 \\
\hline $\begin{array}{l}\text { To compare the costs of different } \\
\text { brands as well as brand and } \\
\text { generic products which } \\
\text { Pharmacoeconomic analysis is } \\
\text { preferred }\end{array}$ & 22 & 78 \\
\hline $\begin{array}{l}\text { Pharmacoeconomic analysis } \\
\text { which measures outcome in } \\
\text { monetary units is------- }\end{array}$ & 18 & 82 \\
\hline $\begin{array}{l}\text { Quality Adjusted Life Years } \\
\text { (QALY) measured in------- } \\
\text { analysis }\end{array}$ & 25 & 75 \\
\hline $\begin{array}{l}\text { To compare the costs of National } \\
\text { Highway project and vaccination } \\
\text { programme which } \\
\text { Pharmacoeconomic analysis is } \\
\text { preferred? }\end{array}$ & 11 & 89 \\
\hline
\end{tabular}

\section{DISCUSSION}

It is well documented that the emerging discipline of pharmacoeconomics has become adopted worldwide as a health science discipline by the pharmaceutical industry, academic pharmaceutical scientists, pharmacy practitioners and health care professionals. ${ }^{14}$

Active participation among postgraduates in this study was very poor. Among these postgraduates only $39 \%$ of residents were having awareness about pharmacoeconomics. Nearly $25 \%$ of the postgraduates were having knowledge relating to pharmacoeconomics and around $20 \%$ of postgraduates have applicable knowledge about pharmacoeconomics.

In our study we noticed that many postgraduates showed little interest and were reluctant to participate eventhough it was told that their identity would be kept confidential. Various reasons for the above could be (a) lack of interest in pharmacoeconomics (b) unawareness about significance of pharmacoeconomics (c) lack of exposure to pharmacoeconomics concept in MBBS curriculum. Therefore, to increase the awareness it is desirable to conduct CME, workshop and symposium in medical colleges which will also help the postgraduates to refresh and update their knowledge. Total $52 \%$ of postgraduates felt pharmacoeconomics should include in postgraduate curriculum. Only $17 \%$ showed self-interest in learning pharmacoeconomics. Our study results were correlate with the Jarinabanu Tahashildar et al, Jeannette EF et al and Dr Madhav K. Savkarei studies. ${ }^{9,15,16}$

Overall residents were having extremely poor awareness and knowledge regarding pharmacoeconomics. Hence, the inclusion of pharmacoeconomic concept and practical exercises in the curriculum of medical undergraduates would help them to realize the enormous differences in cost of various brands available in the market and will also increase their awareness of indirect cost and intangible cost associated with the drug therapy. Secondly, to increase the awareness it is desirable to conduct CMEs, Workshops and symposium in medical colleges which will also help in postgraduates to refresh and update their knowledge. We recommend the further studies to be carried out on large scale involving private practitioners (working in clinics, nursing homes and corporate hospitals) and practitioners of government hospitals (working at primary, secondary, tertiary care levels) which will give more valid results on the level of awareness, knowledge and application of pharmacoeconomics among these professionals.

\section{CONCLUSION}

The present study has revealed that the level of knowledge and awareness of postgraduates about pharmacoeconomics is very poor and limited. Therefore, there is an urgent need to introduce the concept of pharmacoeconomics in the teaching curriculum both at undergraduate and postgraduate level so that the medical professionals are sensitized to this concept at the early phase of their career and this will help them in better decision making regarding pharmacoeconomics in future

Funding: No funding sources

Conflict of interest: None declared

Ethical approval: The study was approved by the Institutional Ethics Committee 


\section{REFERENCES}

1. Bootman JL, Townsend RJ, Mc Ghan WF. Principles of Pharmacoeconomics. $2^{\text {nd }}$ Ed. Cincinnati OH: Harvey Whitney Books Co.; 1996.

2. India Knowledge @ Wharthon, with RSBY, India tries to Curb the Health-based Poverty Trap, May 03, 2012.

3. Corporate Social Responsibility: Pharmaceutical Industry by Prof. RD Joshi; Interlink Insight. 2007;5(4).

4. Spiegel BM, Targownick L, Dulai GS, Grainek IM. The cost effectiveness of cyclooxygenase- 2 selective inhibitors in the management of chronic arthritis. Ann Intern Med 2003;138(10):795-806.

5. The National Pharmaceutical Pricing Authority. Available at: http://www.nppaindia.nic.in/index1.html. [Last accessed on 2016 Jan 05].

6. Available at: http://www.cdsco.nic.in/html/Sec_122_A. [Last accessed on 2011 Jan 08].

7. Dhamend L. Pharmacoeconomics and the Clinician: A South African Perspective, South African Family Practice. 2011;53:1:92.

8. Seth DS. General Pharmacology Introduction. In: Seth DS (editor), Textbook of Pharmacology, 2nd edition. Elsevier; Addendum I; 1999:824.

9. Savkar MK, Bhat PN, Deepika G, Shwetha. Evaluation of pharmacoeconomics awareness among post graduates: a questionnaire based study. Indian Journal of Basic and Applied Medical Research. 2014:3(3):135-41.

10. Jayasree D, Uppu B, Devi BV. A study on awareness of pharmacoeconomics among postgraduates in a tertiary care teaching hospital. Int J Res Med Sci. 2016;4:1597-603.
11. Ross KN, Siniscalco MT, Auriat N. Quantitative research methods in educational planning. Questionnaire design Module 8. International Institute for Educational Planning (C) UNESCO; September 2005:3-4.

12. Foddy W. Constructing questions for interviews and questionnaires. Cambridge: Cambridge University Press; 1993.

13. Oppenheim AN. Questionnaire design, interviewing and attitude measurement. London: Pinter Publishers Limited; 1992.

14. Hass B, Pooley J, Feuring M, Suvarna V, Harrington AE. Health technology assessment and its role in the future development of the Indian healthcare sector. Perspectives in Clinical Research. 2012;3:66-72.

15. Tahashildar J, Kota K, Kumar KS, Mohanty L, Ahmed SY. Assessment of the Knowledge and Perceptions about Pharmacoeconomics among Medical postgraduate students and Healthcare professionals at a Tertiary care teaching hospital, Udaipur, India. International $\mathbf{J}$ of current research and Academic review. 2015;3(2):135-42.

16. Zwart-van Rijkom JE, Leufkens HG, Busschbach JJ, Broekmans AW, Rutten FF. Differences in Attitudes, Knowledge and Use of Economic Evaluations in Decision-Making in The Netherlands the Dutch Results from the Euromet Project. Pharmacoeconomics. 2000;18(2):149-60.

Cite this article as: Gupta R, Malhotra P. Evaluation of awareness about pharmacoeconomics in postgraduate students of a tertiary care teaching hospital: a questionnaire based observational study. Int J Basic Clin Pharmacol 2017;6:2459-62. 